\title{
The BRICS Countries Grouping: Promise of a New Thematic and Methodological Research Focus in the Social Sciences and the Humanities
}

Dr Charl Wolhuter ${ }^{+*}$ and Dr Oxana Chigisheva ${ }^{*}$

\section{Abstract}

The aim of this research, as part of this Special Issue on the thematic and epistemological foci of social science and humanities research emanating in the BRICS countries, is to investigate and to assess the value of such research - firstly, for the BRICS countries mutually, then for the rest of the Global South as well as for the global humanities and social science community at large. The rationale of this research is that the BRICS countries have come to assume a growing gravitas in the world, not only on strength of geography, demography and economy; but also because of the diversity contained in each of these BRICS countries. These diversities offer opportunities to learn a lot from each other, in addition the rest of the gamut of countries in the Global South as well as the nations of the Global North can benefit much from learning from the experience of the BRICS countries. The research commences with a survey of the most compelling societal trends shaping the 21st Century world, which will form the parameters of the context in which scholarship in the social sciences and humanities are destined to be conducted. The state of scholarship in the humanities and the social sciences and the imperatives of context will be the next topic under discussion. Within this landscape, the potential role of research on BRICS soil is then turned to. The BRICS countries are surveyed, then a conclusion is ventured as to their potential as a fountainhead for social sciences and humanities research.

Keywords: Brazil; BRICS; China; Epistemology; Humanities; India; Research Agenda; Russia; Social Sciences; South Africa

\footnotetext{
${ }^{+}$Professor, Comparative and International Education, North-West University, Potchefstroom Campus, South Africa

${ }^{*}$ Corresponding Author, Email: Charl.Wolhuter@nwu.ac.za

¥ Associate Professor, Southern Federal University, Rostov-on-Don, Russia, Email: opchigisheva@sfedu.ru

(C) 2020 Wolhuter \& Chigisheva. This is an Open Access article distributed under the terms of the Creative Commons Attribution License (http://creativecommons.org/licenses/by/2.0), which permits unrestricted use, distribution, and reproduction in any medium, provided the original work is properly cited.
} 


\section{Introduction}

The modern world is dynamical, changing, challenging and competitive (Friedman, 2009; Rosa, 2005). This makes for all countries to seek possibilities for cooperation and learning from each other, especially when solving some pressing national issues (Forrestier \& Crossley, 2015; Ivenicki, 2020; Kamens, 2012; Lane \& Kinser, 2013; Pinger, 2017). One of such cooperation blocks is the BRICS association of five countries (Brazil, Russia, India, China, South Africa), a group of five developing countries and emerging market economies with, given their geographic and demographic weight, and demographic and economic trends, are set to become major players in global politics. It is the thesis of this research that not only their growing gravitas in the world on strength of geography, demography and economy; but also the diversity contain in each of the BRICS countries mean, that not only can they learn a lot from each other, but also both the rest of the gamut of countries in the Global South as well as the Western nations can benefit much from learning from the experience of the BRICS countries.

This research explores and determine the potential value of such research. First, for the BRICS countries mutually, second, for the rest of the Global South, and third, for the global humanities and social science community as a whole.

The research commences with a survey of the most compelling societal trends shaping the $21^{\text {st }}$ Century world. It is assumed that such trends will form the parameters of the context in which scholarship in the social sciences and humanities are destined to be conducted. The state of scholarship in the humanities and the social sciences and the imperatives of context will be the next topic under discussion in this research. Within this landscape, the potential role of research on BRICS soil is then turned to. The BRICS countries are surveyed, and a conclusion regarding the potential value of these countries as a fountainhead for social sciences and humanities research will be tabled.
This is then offered as a frame to read the other contributions to this special issue.

\section{The New World Taking Shape in the 21st Century}

The following is an outline of the most salient trends shaping the world of the early21st Century.

The first trend is the ecological crisis. The global population growth and increasing industrial activity and consumption of an ever more diverse and affluent global population, have result in increasing use and pressure on and use of environmental resources, in addition to increasing amounts of waste products (Friedman, 2009). The main dimensions of the environmental crisis are air pollution (including global warming), depletion and pollution of freshwater resources, pollution of the oceans, deforestation, soil erosion, and the destruction of bio-diversity (World Economic Forum, 2019). This crisis has spawned the idea of "sustainable development". The response of the United Nations that is the global community in its organised form was to formulate the Seventeen Sustainable Development Goals as the international community's vision for the world of 2030 (United Nations, 2019-2). As such, these Seventeen Goals - and the whole concept of "sustainable development" - will strongly impact the activities of scholars in the social sciences and humanities in the next decade. The impact of the ecological crisis on education, in particular, is evident in the INCHEON Declaration, or Education for Sustainable Development - the global community's vision for education by the year 2030 (UNICEF, 2015). Besides, there are several forceful demographic trends. Although slowly slowing down, 90 million people are still added to the global population each year. Differential growth rates characterise the world- roughly a swift growth in the countries of the Global South, and slow growth, in some places even zero or negative growth, in the Global North. These demographic dynamics set their challenges. Perhaps, the first challenge is education, especially the countries of the Global South are under pressure to supply 
education to ever-rising enrolments; while the countries of the Global North face an influx of immigrants, and increasingly multicultural make-up of students in educational institutions (see Esteban, 2020; Wolhuter, 2021).

The age pyramid is changing too. In the countries of the Global North, there is ageing or "greying" of the population, as the most significant growth is in the 65 years plus age group. In the Global South, the biggest growth is in the adult population sector, that is, those in between 15-65 years of age (United Nations, 2019-1). These differential growth patterns with the population increase in the Global South as push factors, as well as political stability and economic affluence in the Global North as pull factors, result in massive scale migrations of the people on earth. The two most salient vectors in these migrations are south to north flow (from the African and South American continents in the south and the Middle East to Europe and North America in the north) and east (from Asia and Eastern Europe) to the West (to North America and Western Europe). Finally, the global population is becoming ever more mobile. These demographic trends shape a new society, and this social matrix will inform the thematic and epistemological foci of social studies in the coming decades. For example, in his oft-cited book, Sociology of Societies: Moblities in the Twenty-First Century, John Urry (2000) contends that mobility, as a new feature of societies, will require a total restructuring of the scholarly field of Sociology (which was historically constructed on the premise of sedentary societies). Concerning education, in particular, the 2019 UNESCO Global Education Monitoring Report carrying the subtitle: Migration, Displacement and Education: Building Bridges, not Walls, has privileged population mobility and presents evidence on the implications of different types of migration for education (UNESCO, 2019).

The ever-expanding frontiers of science, and the exponential increase in technological innovations, will have a significant influence on the future if the experience of the 20th Century is anything to go by (see Toffler, 1980). Particular areas of the unabated scientific and technological progress are agricultural development and transformation, biotechnology, the robot revolution, and above all, the ICT (Information and Communications Technology Revolution) (Friedman, 2009). The information and communication technology revolution has radical implications for knowledge. The stock of knowledge is multiplying at an ever-increasing rate. Furthermore, knowledge is becoming democratised, as everyone has access to knowledge, using electronic media and sources. Technological progress, for example, artificial intelligence, the rise of mass databases and open access resources, as well as the rise of social media and the phenomenon of fake news, present at the same time frightening prospects and open new vistas for the social sciences and humanities, and clothe scholars in these fields with new responsibilities (Blessinger, Senguptagupta \& Mahoney, 2019; Cresswell, Schwantner \& Waters, 2015; Ivenicki, 2020; Harari, 2015, 2018)

On the economic front, the first trend is growing affluence. Since 1990, the world entered one of the longest, most vigorous, and most sustained economic upswings. In the ten years 20052015, the global annual economic output has more than doubled - from US\$29.6 trillion to US\$78.3 trillion (World Bank, 2016), to US\$ 80.684 trillion in 2018 (estimated) (World Bank, 2018). A sizeable part of this growing affluence in the world took part in the BRICS countries, as will be illustrated later in this research.

Despite the growing affluence in the world, there is widespread poverty and gross inequality, although both are decreasing, albeit painstakingly slowly. Eight hundred and thirtysix million people in the world survive on less than US\$1.25 per day (down from 1.923 billion in 1990) (World Bank, 2016). Being two of the most unequal societies on earth, Brazil and South Africa have their part of poverty, while in two of the other BRICS countries, China and India are home to a large part of the people in the world classified by the World Bank as poor.

Since the late 1980s, the neo-liberal economic revolution has commenced, and a global 
economic trend has been taking place. Although it began in the West (Western Europe and North America), it spread to the East (Eastern Europe and Asia), and a short time later spread to Africa and South America. The role of the state in the economy became reduced, and market forces became more dominant. This neo-liberal economic revolution has hit all five BRICS countries suddenly and forcefully the past forty years, albeit in different ways (see Brock, 2013: 157-176).

Another forceful economic trend is that of economic internationalism and globalisation. The world economy is becoming more and more integrated, due to, among other things, the communication technology revolution, the fading of the nation state (to be discussed below), and the role of the World Bank and the International Monetary Fund. Multinational companies are becoming increasingly prominent, and a massive international financial market, which operates $24 / 7$, is evolving.

The rise of knowledge economies presents another strong economic trend, that is an economy where the production and consumption of new knowledge have become the driving axis of economic development. While the development of knowledge economies is especially topical in the Global North; in the Global South, a conspicuous development, is the rise of the informal economic sector (see Alcock, 2018). This, of course, stems from the economic liberalisation and withdrawal of state dominance (discussed above) and the contraction of the state and its range of activities (discussed below, under political trends).

Turning on to social trends, the relative importance of primary, secondary and tertiary groupings in society is changing. The dominance of the primary social grouping, that is, the family, is on the decline, including in the BRICS societies (OECD , 2011). This applies to both roles of family members and lifestyle. The family is no longer a production or consumption unit or entertainment grouping it used to be. The core family, consisting of a husband, a wife, and two children, is no longer the modus, or the norm, to the extent that it used to be.

The secondary social grouping, that is, the workplace, which is also decreasing in importance because of a decrease of the percentage of people that have a "job for a lifetime" is dropping, and the prevalence of contract work, temporary work, and people working from home is increasing. Besides, the workplace is being affected by the rise of the informal economic sector and an increase in selfemployment. Tellingly the World Bank's (2019), World Development Report, in which this changing nature of work is depicted, carries the subtitle of The Changing Nature of Work (World Bank, 2019). Tertiary social groupings that is, functional interest groups, such as sports clubs and hobby clubs, by contrast, are rising in prominence due to trends such as the empowerment of interest groups by the information technology revolution.

Other social trends include the rise of multicultural societies and the empowerment of minorities. These can be traced back to the increased mobility of people, the ICT revolution, and the rise of the Creed of Human Rights.

Politically the first compelling trend is the demise of the once omnipotent nation-state (Davidson \& Rees-Mogg, 1992). The information and communication revolution, as discussed above, the globalisation of economies, and downscaling of the activities of the state- all contribute towards the erosion of the power of the state.

With regard to erosion of the power of the nation-state, the locus of power is shifting from the nation-state in two opposite directions: upward towards supranational (of which the European Union is perhaps the best example) and international structures (examples of this include the role of the World Bank and the International Monetary Fund) (see Kamens, 2012) and downwards towards sub-national and local structures (Ebel \& Yilmaz, 2003).

Two related political and political-social trends are democratisation and individualisation. Democratisation has spread impressively the 
past half a century. In 1974 there were 41 democracies worldwide; by 1991 this had shot up to 76 out of 169 countries, and by 2005 there were 123 democracies in the world (Mills et al., 2019: 4). Democratisation, the empowering power of the ICT revolution and the Creed of Human Rights all give impetus to the rising importance attached to and experienced by the individual.

Four religious and life-philosophical trends can be identified in contemporary society. Firstly, despite claims that the present age is a postreligious, secular age, religion continues to be present (see Pew Research Center, 2012), albeit in a more complex form that in the past. Religion persists as an essential factor in individual lives, and in social dynamics. However, three aspects complicate matters further. One of them is the existence of multi-religious societies (Abu-Nimer \& Smith, 2016), which is part of the multicultural make-up of modern societies, as explained above. Secondly, many people consider themselves to be religious but do not belong to an organised religious community. Thirdly, people no longer fit into neat categories such as "Christian" or "Sikh Muslim" but put together their own individualised belief systems (Van der Walt, Potgieter \& Wolhuter, 2010).

Two other life-philosophical trends are firstly the proliferation of the Western, individualistic, materialistic outlook to all corners of the world. Secondly the Creed of Human Rights as a basis for a new moral order, have found subscription virtually all over the world including BRICS countries (Brazil, India and South Africa). Van Lindert (2016) sees a new role for such countries in new world order. The final trend is the rise of interculturalism and intercultural education. In recent years, particularly after the 9/11 terrorist attack, it seems as if the philosophy of multiculturalism and the pedagogy of multicultural education have been superseded by a philosophy of interculturalism and the pedagogy of intercultural education all over the world (including in BRICS countries) (see Avenicki, 2019). Markou (1997) explains the four principles of intercultural education:
- Education with empathy, which means showing deep understanding for others, and trying to understand their position;

- Education with solidarity, which means that an appeal is directed to the cultivation of a collective conscience, and the promotion of social justice;

- Education with intercultural respect; and

- Education with ethicist thinking, which assumes the presence of dialogue.

\section{The Caveats of the Social Sciences and Humanities}

In this world of rising knowledge societies and knowledge economies, as outlined above (when discussing economic trends), it is logical that the Social Sciences and Humanities are looked onto to steer humanity through this world (Blessinger et al., 2019; Harari, 2018: 259-268). This is doubly so in an age of neoliberal economic revolution (as explained above), when the calls for relevance and a demonstrable return to investment have also been carried into the education sector ( $c f$. Wolhuter, \& Van Der Walt, 2019). While mindful of the dangers of civil society ceding control to a dispensation of a technocractic society, as cautioned by Habermas (1968), or an "algogracy" (that is, where algorythms rule humans, such as where the results of large scale test series such as the PISA or TIMSS tests give rise to algorythms which dictate education reform policy decisions, that is, where humans are reduced to values on algorythms) (Wiseman \& Davidson, 2018). This is a call which the Social Sciences and Humanities - as a matter of their survival at universities will have to heed to. David Blunkett (2000: 1221), at that stage head of the Department of Education and Employment in the United Kingdom, stated: "...we need social scientists to help to determine what works and why, and what types of policy initiatives are likely to be most effective". A strong impulse emanates from the new societal context of the 21st Century to scholars in the social sciences and humanities, to design the compass to steer humanity to a humane future. However, there are a number of features pertaining to the nature of the subject of these fields, and also 
pertaining to present features regarding scholarly activities in these fields, which makes it difficult for these fields to live up to these expectations of society. It is to these problematic features that the article will not turn to.

The Social Sciences and Humanities simply cannot match the Natural Sciences in its demonstrable, concrete evidence of impact on praxis and decision-taking or policy formulation. Hence it would be futile to look for such reliable guidance from scholars in these fields regarding the negotiation of the 21st Century context by humanity. In the Education Sciences - by no means untypical of the Social Sciences Wolhuter (2019) writes that despite all the pressures towards relevance, there is a nagging feeling, substantiable by reports appearing with regular monotony in the scholarly literature, that Education research lacks relevance, is wrapped up in an ivory tower, removed from the everyday reality of schools and classroom. Pollard (2007: 125) alleges that Education research in the United Kingdom is perceived as "... being small scale, irrelevant, inaccessible and low quality".

Related to the problem of low impact, and in fact, possibly one of the causes thereof is the problematic nature of generalisation in the Social Sciences and the Humanities. Patterns and regularities in the subject of study of these fields are highly context-bound. Coetzee (1990) for example, has surveyed tens of studies done in the two decades up to his research, calculating a correlation between birth rates or fertility (dependent variable) and level of education (as the independent variable) of women. These studies yielded widely divergent results: positive correlation, no correlation, negative correlation, or curvilinear relationships; depending on societal contextual factors (geography, demography, social factors, economy, political factors, and religious and philosophical life factors). Wolhuter et al. (2011) studied Comparative and International Education students' reasons for enrolling in the course of Comparative and International Education in six sovereign countries, and found that these motivations are unique in each country, and can be related to the national context in which students found themselves. It seems that scholars in the Social Sciences and Humanities would be well advised, in the interpretation of the results of their studies, to use silos of similar contexts as a conduit or interim station when searching for regularities, as the subjects of Social Studies defy the iron or universal laws found in the Natural Sciences. That offers the best hope society can harbour regarding guidance from these fields in humanity's quest to come to terms to and to best exploit the chances offered by the new $21^{\text {st }}$ Century context.

However, this leads to the next problem, especially if Social Science scholars decide to go the way of employing contextual conduits in an attempt to derive statements on regular patterns. The publications in the Social Sciences show highly uneven patterns when it comes to the geography of authorship and terrain covered. For example, in analysing articles of 18523 authors s published in 2012 in 219 Thomson Reuters indexed journals in the field of Education, Wolhuter (2017) found that extremely uneven patterns emerged. This research, using content analysis as a method, found that almost half of all the countries did not register a single author in this total pool of 18523 authors. Close to ninety per cent of the authors resided in the North American and Western European primary hub, and the Asian-Pacific weaker secondary hub of the international network of Education scholars. In analysing the geographical focus of articles published during the first fifty years of the existence of the Comparative Education Review, a top journal in the field of Comparative and International Education, a similar very uneven pattern was found (cf. Wolhuter, 2008). Strielkowski \& Chigisheva (2018) explain how the world publication forum is tilted in favour of the historical node and acknowledged top researchers, nonetheless - and noteworthy for supporting the thesis of this research - nations such as Russia and China are making headway against this. 


\section{The BRICS Supra-National Unit}

This section will now focus on the BRICS supranational grouping as a unit for generalisation in Social Science research. It will deal with the power and place of the BRICS grouping in global geopolitics, and at both the similarities between the BRICS countries and the contrasts between the BRICS countries on the one hand, and the rest of the world on the other.

\section{Geography}

The surface areas of the BRICS countries, and the relative size of these countries to all countries in the world, are presented in Table 1.

\begin{tabular}{|l|l|l|}
\multicolumn{2}{|c|}{ Table 1: The Geographic Weight of the BRICS Countries in the World } \\
\hline $\begin{array}{l}\text { Rank Order in terms of Size } \\
\text { among all countries in the } \\
\text { world }\end{array}$ & Country & $\begin{array}{l}\text { Surface Area (millions of } \\
\text { square kilometres) }\end{array}$ \\
\hline 1 & Russia & 17.1 \\
\hline 4 & China & 9.6 \\
\hline 5 & Brazil & 8.5 \\
\hline 7 & India & 3.2 \\
\hline 25 & South Africa & 1.2 \\
\hline Source: ??? & & \\
\hline
\end{tabular}

Together the BRICS countries cover 29.6 million square kilometres, or 19.9 per cent of the total area of 148.9 million square kilometres, covered by all countries in the world put together. This represents a significant part of the world, offering an impressive swathe of territory for

\begin{tabular}{l|l}
\hline \multicolumn{2}{|l|}{ Table 2: The Demographic Force of the BRICS Countries in the World } \\
\hline Country & Population (millions) \\
\hline Brazil & 207.8 \\
\hline China & 1371.2 \\
\hline India & 1311.1 \\
\hline Russia & 144.1 \\
\hline South Africa & 55.0 \\
\hline BRICS (Share of global population) & $42 \%$ \\
\hline Source: World Bank, 2018 &
\end{tabular}

being the terrain of social science and humanities research.

\section{Demography}

The demographic force of the BRICS countries in the world is presented in Table 2 .
Together the BRICS countries are home of almost half the global population, once again this, as the case of its geographic weight, demographically the BRICS countries represent a force in the world, and a rich field for research for scholars from the social sciences and the humanities.

\section{Economy}

In terms of the World Bank classification, Brazil, Russia, China and South Africa are upper middleincome countries, while India is a lower middleincome country. The BRICS block of countries represents a sizeable and growing part of the global economic output, as is evident from Table 3.

Economists at Goldman Sachs predicted that by 2050 the economic output of the BRICS group would surpass that of the G7 countries (seven most advanced countries) (Goldman Sachs, 2010).

\section{Social system}

The BRICS countries are very diverse. Socioeconomic disparities are rife. The Gini indices in these countries are of the highest in the world: South Africa 62.5 (2nd in the world), Brazil 49.0 
(19th), China 46.3 (29th), Russia 41.2 (57th) and India 35.2 (95th) (Central Intelligence Agency, 2019). South Africa's Constitution recognises eleven official languages and the Constitution of India recognises twenty-two. In Russia, thirty languages used in various parts of the country are officially recognised, while the Constitution of China recognises fifty five ethnic minorities. However, in each case, the language pattern is even more complicated. While ninety-eight per cent of the population of Brazil speaks Portuguese as the first language, there is a myriad of Amerindian languages, which are also spoken at great length.

\section{Table 3: Gross National Income of BRICS Countries (Billions of US\$\$)}

\begin{tabular}{|l|l|l|}
\hline Country: & $\mathbf{2 0 0 5}$ & $\mathbf{2 0 1 5}$ \\
\hline Brazil & 662.0 & 2076.1 \\
\hline China & 2269.7 & 10838.1 \\
\hline India & 804.1 & 2088.5 \\
\hline Russia & 638.1 & 1676.0 \\
\hline South Africa & 223.5 & 334.2 \\
\hline BRICS Total & 4597.4 & 17012.9 \\
\hline \% of global economic output & 10.2 & 21.9 \\
\hline
\end{tabular}

Sources: World Bank, 2007, 2018.

\section{Politics}

All five BRICS countries have in the not distant past become rather fast part of the international world. This modern international world poses its twin demands of democracy and Human Rights as criteria for acceptance. India became independent in 1947 (still within living memory of many) and has been ever since the largest democracy in the world. In the years following the Fall of Berlin Wall in 1989, Russia, Brazil and South Africa became full democracies in the Western liberal sense of the word. In 1979, China re-entered the fold of the international community after thirty years of isolation from the rest of the world.

\section{Religion and Life and World Philosophy}

Samuel Huntington (1996) mapped the religion and life and world philosophical patterns in the world after the conclusion of the Cold War, as consisting of the following civilisation blocs: The Western (Western Europe, North America, Australia, New Zealand), The Orthodox (Eastern Europe), Hindu, Buddhist, Confucian, Shintoist, Islam, Sub-Saharan Africa and Latin American. He painted the world in the broadest brush strokes then as a conflict between the West and the Rest. Without subscribing wholly to this oversimplified view of the world the BRICS countries, by virtue of their geographic, demographic and economic weight, represent the vanguard of five of the other poles in the world. The significance of this for advancement in the scholarly project is incalculable, as will be explained now.

\section{Conclusion}

In the current, post-1990 world, the power behind the Pax Americana and the technology available in the age of globalisation, see to it that the Western liberal democratic model is being rolled out around the globe, a process predicted by Francis Fukuyama. As part of this process come the materialism, individualism, and a consumer-culture, associated with the West. However, at the same time, as these global processes are rolled out from the West to the rest of the world, they run into a number of other civilisation blocs, as explained by Huntington (1996), each with a hierarchy of values that doe not totally correspond to, and may even contradict, that of the Western liberal system of values. In this dialectic between global and local; new contexts are created. Actually, even Huntington's model can be argued as being too simplistic, as the technological revolution and Creed of Human Rights make for far more diversity than the dozen civilisation blocs described by Huntington (1996). This process has, ironically, been depicted by none other than Fukuyama (2018) in his latest book. 
In the unfolding century of knowledge economies, the role of research in guiding societies and economies to hold their own and to progress in a globally competitive world will depend more than ever before on knowledge and knowledge production. However, the incubator and hothouse of knowledge production in the world today is the Western Europe-North America node. As social science and humanities knowledge, in particular, are context-contingent, this uneven pattern of knowledge production works to the detriment of the extra-Western world. The best hope the extra-Western world has of escaping this grip is from the BRICS constellation. These are not only in terms of geographic and growing demographic and economic weight the rising antipodes in civilisation blocks outside the West, but the formal BRICS group formation, and the immanent BRICS university, offer the best promise for research themes and epistemologies to be developed in extra-Western context in a concerted, muscular effort by a consortium of scholars outside the Western bloc. The BRICS countries showing traits in the contemporary world such as diversity, in the extreme, mean the value of research themes explored and epistemologies developed in the BRICS countries, can be of value to even modern Western societies and contexts; where these societies too are becoming ever more diverse.

\section{References}

Abu-Nimer, M. \& Smith, R.K. (2016).

Interreligious and intercultural education for dialogue, peace and social cohesion.

International Review of Education 62(4): 393405.

Alcock, G.G. (2018). KasiNomicsL The rise of Africa's informal economics. Bryanston:

McDonald Publishers.

Blessinger, P., Sengupta, E. \& Mahoney, C. (2019). Towards higher education for a better civil society. University World News. Retrieved on 9 December 2019 from, https://www.universityworldnews.com/post.ph p?story $=20191202120655146$
Blunkett, D. (2000). Influence of Irrelevance:

Can Social Science Improve Government? Secretary of State, ESRC Lecture, 2 February 2000. ESRC/DfEE, London. Reprinted in Research Intelligence, 71, 12-21.

Brock, C. (2013). Education Around the World: A comparative introduction. London: Bloomsbury.

Central Intelligence Agency (CIA). 2019. World Factbook. Retrieved on 9 December 2019 from, https://www.cia.gov/library/publications/theworld-factbook/rankorder/2172rank.html

Coetzee, D.D.J. (1990). Die Invloed van Onderwys op Bevolkingsaanwas. Unpublished Masters of Education Dissertation, University of Stellenbosch.

Cresswell, J., Schwanter, U. \& Waters, U. (2015). A Review of International Large Scale

Assessments in Education: Assessing component skills and collecting contextual data. PISA for Development. Paris: OECD. Retrieved on 9 December 2019 from, http://dx.doi.org.nwulib.nwu.ac.za/10.1787/97 89264248373-en

Davidson, J.D. \& Rees-Mogg, W. (1992). The Great Reckoning: How the world will change in the depression of the 1990s. London: Sidgwick \& Jackson.

Ebel, R.D. \& Yilmaz, S. (2003). Globalization and Localization: Decentralization Trends and Outcomes Paper Prepared for the Developing and Strengthening System of Intergovernmental Fiscal Relations and Fiscal Decentralization A Joint Conference of World Bank Institute and Korea Development Institute, Seoul, Korea, July 21 23, 2003. Retrieved on 9 December 2019 from,

http://www.kdi.re.kr/upload/7050/I_KwangCho i.pdf

Esteban, A.N. (2020). El derecho a la educación de los menores refugiados y solicitantes de asilo desde el enfoque basado en los derechos humanos: dificultades, finalidad e intervención educativa. Revista Española de Educación Comparada, 35, 70-91. 
Forrestier, K. \& Crossley, M. (2015).

International education policy transfer borrowing both ways. Compare, 45(5), 664-685.

Friedman, T.L. (2009). Hot, Flat and Crowded: Why the worlds needs a green revolution - and how we can renew our global future. London: Penguin.

Fukuyama, F. (1992). The End of History and the Last Man. New York: Free Books.

Fukuyama, F. (2018). Identity: The Demand for Dignity and the Politics of Resentment. New York: Farrar, Straus and Giroux.

Goldman Sachs. (2010). Building better global economic BRICs. Retrieved on 9 December 2019 from, www2.

goldmansachs.com/ideas/brics/building-betterdoc.pdf

Habermas, J. (1968). Technik und Wissenschaft als „Ideologie", Suhrkamp, Frankfurt am Main 1968.

Harari, Y.N. (2015). Homo Deus: A brief history of tomorrow. London: Harvill Secker.

Harari, Y.N. (2018). 21 Lessons for the $21^{\text {st }}$ Century. London: Jonathan Cape.

Huntington, S.P. (1996). The Clash of Civilizations and the Remaking of World Order. New York: Simon \& Schuster.

Ivenicki, A. (2020). Multicultural Brazil in the BRICS Countries: Potentials for the Social Sciences and Humanities. Journal Space and Culture, India, 7(5): 14-22 https://doi.org/10.20896/saci.v7i5.641

Kamens, D.H. (2012). Beyond the Nation-State: The reconstruction of nationhood and citizenship. London: Emerald.

Lane, J.E. \& Kinser, K. (2013). Cross-border higher education in Africa: Collaboration and competition. In: Wiseman, A.W. \& Wolhuter, C.C. (eds). 2013. The Development of Higher Education in Africa: Prospects and challenges. Bingley, UK: Emerald: 99-126.

Markou, G. (1997). Introduction to Intercultural Education. Athens: Pappas Bros.
Mills, G., Obasanjo, O., Herbst, J. \& Biti, T. (2019). Democracy Works: Rewiring politics to Africa's advantage. Johannesburg: Pan Macmillan.

OECD (2011). Families are Changing. Retrieved on 9 December 2019 from, https://www.oecd.org/els/soc/47701118.pdf

Pew Research Center. (2012). The global religious landscape. Retrieved on 9 December 2019 from, www.pewforum.org/2012/12/18/globalreligious-landscape-exec/

Pingel, F. (2017). Nationa, Supranational Communities and the Globa. In: Bellino, M.J. \& Williams, J.H. (eds). Constructing Memory: Education, identity and context. Rotterdam: Sense: 313-333.

Pollard, A. (2007). The United Kingdom's Teaching and Learning Research Programme, In: Burns, T. \& Schuller, T. (eds). Evidence in Education: Linking Research and Policy, OECD, Paris: 125-141.

Rosa, H. (2005). Beschleunigung: Die Veränderung der Zeitstrukturen in der Moderne. Frankfurt am Main: Suhrkamp.

Strielkowski, W., Chigisheva, O. (2018). Research Functionality and Academic Publishing: Gaming with Altmetrics in the Digital Age. Economics \& Sociology, 11(4), p. 306-316.

Toffler, A. (1980). The Third Wave. New York: Bantam.

UNESCO (2019). Global education monitoring report, 2019: Migration, displacement and education: building bridges, not walls. Paris: UNESCO, Retrieved on 9 December 2019 from, https://unesdoc.unesco.org/ark:/48223/pf0000 265866

UNICEF (2015). Incheon Declaration: Education 2030: Towards Inclusive and Equitable, Quality Education for All. New York: UNICEF.

United Nations. (2019-1) Sustainable Development Goals. Retrieved on 9 December 2019 from, https://sustainabledevelopment.un.org/?menu $=1300$ New York 
United Nations (2019-2). World Population Prospects 2019. New York: United Nations. Retrieved on 9 December 2019 from, https://population.un.org/wpp/Publications/Fil es/WPP2019_Highlights.pdf Date of Urry, J. (2000). Sociology beyond Societies: Mobilities for the Twenty-First Century. London: Routledge.

Van der Walt, J.L., Potgieter, F.J. \& Wolhuter, C.C. (2010). The Road to Religious Tolerance in South Africa (and Elsewhere): a Possible "Martian Perspective" Religion, State \& Society 38(1): 29-52

Van Lindert, T. (2016). The International Human Rights in a Multipolar/ Humanity in Action, Retrieved on 9 December 2019 from, https://www.humanityinaction.org/knowledge _detail/the-international-human-rights-regimein-a-multipolar-world/?lang=nl

Wiseman, A.W. \& Davidson, P. (2018). The Rhythmic Application of Evidence-Based Policy in National Education Systems Worldwide. In:

A.W. Wiseman \& P. Davidson (eds). Crossnationally Comparative, Evidence-based Educational Policymaking and Reform. London: Emerald: 1-35.

Wolhuter, C.C. (2008). Review of the Review: constructing the identity of comparative education. Research in Comparative and International Education 3(4): $323-344$.

Wolhuter, C.C. (2017). The Geography of Authorship Regarding Research in Education. Croatian Journal of Education 19(3): 981-1000.

Wolhuter, C.C. (2019). Relevance, Rigour and Restructuring: The 3Rs as compass for a community of scholars in need of direction. In: Wolhuter, C.C., Botha, C. \& Vos, D. (eds). Education Studies in South Africa: The quest for relevance, authenticity and responsiveness. Durbanville: AOSIS. Forthcoming.

Wolhuter, C.C. (2021). Terra nova: The Global Education Response. In: Wolhuter, C.C. \&
Wiseman, A.W. (eds). World Education Patterns: The ebb of global forces and the flow of contextual imperatives. Bingham; Emerald. Forthcoming.

Wolhuter, C.C., Sullivan, M.O., Anderson, E., Wood, L., Karras, K.G., Mihova, M., Torres, A., Anangisye, W.A.L., Maarman, R.F., Al-Harthi, H. \& Thonghew, S. (2011). Students' expectations of and motivations for studying comparative education: A comparative study across nine countries in North America, Europe, Asia, Africa and Latin America. Educational Research 2(8): 1341-1355.

Wolhuter, C.C. \& Van der Walt, J.L. (2019). NeoLiberalism and the Human Rights Creed:

Conflicting forces vying for control of the global education agenda. South African Journal of Education 39(4). Forthcoming.

World Bank. (2007). World Development Indicators 2007. Washington, DC: The World Bank Group.

World Bank. (2016). World Development Indicators 2016. Washington, DC: The World Bank Group.

World Bank. (2018). World Development Indicators. Retrieved on 9 December 2019 from, https://data.worldbank.org/indicator/NY.GDP. MKTP.CD?view=chart Date of World Bank. (2019). World Development Report 2019:The Changing Nature of Work.

Washington DC: The World Bank. Retrieved on 9 December 2019 from, http://documents.worldbank.org/curated/en/8 16281518818814423/pdf/2019-WDR-

Report.pdf

World Economic Forum. (2019). The Global Risks Report, 14th edition. Retrieved on 9 December 2019 from, http://www3.weforum.org/docs/WEF_Global_ Risks_Report_2019.pdf Geneva: World Economic Forum. 